\title{
EVALUATION OF TEMPORAL, SEASONAL AND GEOGRAPHIC STABILITY OF THE MOLLUSCICIDAL PROPERTY OF Euphorbia splendens LATEX
}

\author{
Virginia Torres SCHALl, Mauricio Carvalho de VASCONCELlos, Ana Luiza VILLAÇA-COELHo,
} Fátima Eliana FERREIRA-LOPES \& Ivonise Paz da SILVA

\begin{abstract}
SUMMARY
Laboratory tests with aqueous solutions of Euphorbia splendens var. hislopii latex have demonstrated seasonal stability of the molluscicidal principle, with LD90 values of $1.14 \mathrm{ppm}$ (spring), $1.02 \mathrm{ppm}$ (fall), $1.09 \mathrm{ppm}$ (winter), and $1.07 \mathrm{ppm}$ (summer) that have been determined against Biomphalaria tenagophila in the field. Assays on latex collected in Belo Horizonte and Recife yielded LD90 values similar to those obtained with the reference substance collected in Rio de Janeiro (Ilha do Governador), demonstrating geographic stability of the molluscicidal effect. The molluscicidal action of aqueous dilutions of the latex in natura, centrifuged (precipitate) and lyophilized, was stable for up to 124 days at room temperature (in natura) and for up to 736 days in a common refrigerator at 10 to $12^{\circ} \mathrm{C}$ (lyophilized product). A $5.0 \mathrm{ppm}$ solution is $100 \%$ lethal for snails up to 13 days after preparation, the effect being gradually lost to almost total inactivity by the 30 th day. This observation indicated that the active principle is instable. These properties together with the wide distribution of the plant, its resistance and adaptation to the tropical climate, its easy cultivation and the easy obtention of latex and preparation of the molluscicidal solution, make this a promising material for large-scale use in the control of schistosomiasis.
\end{abstract}

KEY WORDS: Euphorbia splendens; Molluscicidal Plants; Biomphalaria sp.; Schistosomiasis.

\section{INTRODUCTION}

The molluscicidal activity of "coroa de Cristo" (Euphorbia splendens var. hislopii) latex has been demonstrated by VASCONCELLOS \& SCHALL (1986), proving that this is a natural substance with high potential for large-scale use in the control of schistosomiasis.

Many plants are being tested as molluscicides all over the world, as indicated by reviews by KLOOS \& MCCULLOUGH (1987), who reported 571 species studied, in addition to approximately 500 plants tested in China (KUO, 1987) and 344 in Brazil (JURBERG et al, 1989). The last authors emphasized two species of the family Euphorbiacea (one of them being E. splen. dens) and one of the family Sapindacea which induce $100 \%$ mortality at concentrations below $10 \mathrm{ppm}$, among 26 other species of several fami- 
SCHALL, V. T.; VASCONCELLOS, M. C. de; VILLAÇA-COELHO, A. L.; FERREIRA-LOPES, F. E. \& SILVA, I. P.

da - Evaluation of temporal, seasonal and geographic stability of the molluscicidal property of Euphorbia splendens latex. Rev. Inst. Med. trop. S. Paulo, 34(3): 183-191, 1992.

lies that are lethal at concentraions below 100 ppm.

Among the species of the genus Euphorbia tested as molluscicides, particularly interesting are E. gymnoclada(SILVA et al, 1971), E. cotinifolia (PEREIRA et al, 1978) and E. lactea (ABOUL EL HASAN et al, 1980), which have been studied in terms of aqueous, alcohol or hexane extraction processes of parts of the plants (stem, leaves, roots). Experiments have been conducted by JURBERG et al, (1985) on E. tirucalli and by VASCONCELLOS \& SCHALL (1986) on E. splendens to test aqueous latex solutions on vector snails of schistosomiasis. SINGH \& AGARWAL (1988) also tested the latex of 4 Euphorbia species against Lymnaea acuminata, the intermediate host of Fasciola hepatica, with positive results.

Among the plants tested against BiomphaIaria sp., E. tirucalli (avelos) is quite toxic to other animals and to humans (PIO CORREA, 1931), and E. cotinifolia is also very toxic to the human skin (RIZZO \& ${ }^{\prime 2}$ ORFIRIO, 1971). These authors applied E. splendens latex to their own skin and noted only a slight passing irritation, concluding that this is the least toxic of the three plants of the same family tested. More recent tests on mice have shown that lethal doses (acute toxicity) and sublethal (repeated) doses are much higher than the LD90 detected for snails (MATTOS et al, 1989). It was also demonstrated low toxicity for the skin and eyes of rabbits (FREITAS et al., 1990). Microbial mutagenicity bioassays have also demonstrated that the latex has no mutagenic activity (SCHALL et al., 1991) at the concentrations tested.

Other assays have shown that E. splendens also has medicinal effects, as reported by RAO \& SUSSELA (1982), who, in a chemical study of the plant, isolated a few steroids, one of which (citrostadienol - Ia) known to have anti-inflammatory activity. As reported by LEE et al, (1982), the stem, roots and latex of E. splendens are used in Chinese folk medicine as natural remedies for hepatitis and abdominal edema. In a study of chloroform extract of the stems and leaves of the plant, these investigators identified a substance, lasiodiplodine, which has anticancerigenic properties, i.e., it inhibits the growth of leukemic lymphocytes. No reference to nega- tive effects of E. splendens has been made in the NAPRALERT system (FARNSWORTH et al, 1981).

Samples of Euphorbia milii, synony m to E. splendens were studied by MARSTON \& HECKER (1983, 1984). The authors identify several diterpene (miliamines $A$ to $I$ ) that exhibit, at the most, an irritant activity, neither of them are tumor promoters. Therefore, tests should be done to investigate the possible presence of phorbol esters in hislopii variety.

These data indicate that $\mathbf{E}$. splendens latex is a promising substance for use as a molluscicide, since it satisfies most of the criteria pointed out by MOTT (1987) as recommended by the WHO for this use, i.e., it is lethal to snail vectors of schistosomiais at low concentrations, it is easy to extract and to prepare, and can be directly manipulated by the population of endemic areas, which is mostly involved in agricultural activities.

In view of these favorable characteristics, the objective of the present study was to evaluate the possibilities of utilizing the product in natura throughout the year and to keep it under different storage and temperature conditions, in order to facilitate its use and expand the possibility of use on any type of occasion and in different aquatic environments.

\section{MATERIAL AND METHODS}

\section{Plant Description}

According to PIO CORREA (1931), Euphorbia splendens is an ornamental plant originating from Madagascar and introduced into Brazil where it is grown in gardens as a living fence. It is commonly known as "bem-casados" (happily married) and "coroa de Nossa Senhora" (Our Lady's crown) in Minas Gerais, "duas amigas" (two girl friends) in Bahia, "martirios" (martyrdom) in other regions, and "Coroa de Cristo" (Crown of Christ) in Rio de Janeiro. The plant consists of a short shrub with long and contorted branches covered with many thorns, leaves bunched at the tip of the branches, and small red bracts. The variety tested in the present study is hislopii, which reaches a larger size. Plant ma- 
SCHALL, V. T.; VASCONCELlOS, M. C. de; VILIAÇA COELHO, A. L.; FERREIRA-LOPES, F. E. \& SILVA, I. P. da - Evaluation of temporal, seasonal and geographic stability of the molluscicidal property of Euphorbia splendens latex. Rev. Inst. Med. trop. S. Paulo, 34(3): 183-191, 1992.

terial has been identified in the Botany Department, National Museum, Rio de Janeiro.

\section{Snails}

The animals used in the experiments were of the species Biomphalaria tenagophila, collected in the field in the Alto da Boa Vista, Agua Santa, Vista Alegre and Pendotiba areas (Rio de Janeiro), with a shell diameter ranging from 10 to $14 \mathrm{~mm}$, and of the species Biomphalaria glabrata, reared in the laboratory and originally from Touros (RN), with a shell diameter of $12 \pm 1 \mathrm{~mm}$

Latex extraction and preparation of latex dilutions and concentrations

For the assays performed in the present study, latex samples of proven mulluscicidal ability were always collected at the same site (Ilha do Governador, Rio de Janeiro) to avoid possible variations due to factors such as soil, climate etc., which affect plant metabolism and active substance concentration, as demonstrated by LUGT (1987).

White latex was drained into test tubes after tapping the stem of the plant with a scalpel incision. The tubes were hermetically sealed and carried to the laboratory for the preparation of mother solutions and of the desired concentration, which procedure was described by JURBERG et al., (1985).

\section{Tests with the mollusks}

The experiments were performed according to the methodology recommended by the WHO $(1965,1983)$.

In all assays, the animals were exposed for 24 hours (period of exposure) to the various latex concentrations, and a control group was exposed only to the diluent (distilled water). Thirty animals per concentration were divided into two groups of 15 snails each and placed in two 1000 $\mathrm{ml}$ beakers (experiment and replicate) each containing a $750 \mathrm{ml}$ volume $(50 \mathrm{ml}$ per animal). During the period of exposure the flasks were left at room temperature and the animals were not fed.
At the end of the period of exposure, the animals were removed from the flasks, washed and rinsed several times in distilled water to remove excess molluscicidal solution. The control snails were similarly washed to standardize handling, and dead snails were counted. After this the snails were returned to the beakers, now containing only distilled water, and left there for 24 hours. During this period they were fed round lettuce leaf slices ( 5 slices measuring 2 cm each per flask).

After this phase, surviving and dead animals were counted and the lethal doses (LD90 and LD50) were computed by probit analysis (FINNEY, 1971).

Such tests of this type were performed during each season of the year to determine possible seasonal variations of the molluscicidal effect, the latex being used no more than on day after its collection. Latex samples from two other regions (Belo Horizonte and Recife) were also test of to determine possible geographic variations.

\section{Evaluation of storage time effect on Mollusci- cidal activity}

Storage time efect was evaluated using 1) latex in natura collected and stored in sealed test tubes maintained at room temperature, 2) centrifuged latex. Centrifugation was carried out at 2500 r.p.m. for 5 minutes at room temperature, resulting after latex heating, in separation of a precipitate and a supernatant. The active portion (deposit) was tested immediately after centrifugation or after storage at room temperature. 3) Lyophilized latex obtained by processing in an Edwards apparatus over 48 hours. The lyophilized material was tested immediately after preparation or after a period of storage at room temperature and in the refrigerator. The lyophilized material was diluted with distilled water containing $3 \%$ ethanol $(\mathrm{v} / \mathrm{v})$.

\section{Evaluation of the durability of the mollusci- cidal effect}

Two $30 \times 45 \times 70 \mathrm{~cm}$ aquaria were prepared with a standard substrate used to rear snails in the laboratory. One was filled with 80 liters of filtered and dechlorinated water (control), and 
SCHALL, V. T.; VASCONCELLOS, M. C. de; VILLAÇA-COELHO, A. L.; FERREIRA-LOPES, F. E. \& SILVA, I. P da - Evaluation of temporal, seasonal and geographic stability of the molluscicidal property of Euphorbia splendens latex. Rev. Inst. Med. trop. S. Paulo, 34(3): 183-191, 1992.

the other with 80 liters of a solution of $\mathbf{E}$. splendens latex at 5.0 ppm concentration. Successive tests were carried out on 30 animals (15 per aquarium) to evaluate the durability of the molluscicidal effect. One day after the introduction of the snails, both aquaria were inspected daily and dead snails were counted and removed. The animals that survived the experiment were marked and returned to the aquarium together with 15 new snails. Seven tests were conducted, for a total duration of 31 days. On the 26 th day, the bottom of the 2 aquaria was stirred and new groups of 15 animals each were introduced to determine a possible sedimentation of the latex.

\section{RESULTS}

Seasonal and geographic evaluation of the molluscicidal activity of Euphorbia splendens latex

The tests described in the previous section demonstrated stability of the molluscicidal effect over the seasons of the year. LD90 was 1.14 ppm (spring), $1.02 \mathrm{ppm}$ (fall), $1.09 \mathrm{ppm}$ (winter) against B. tenagophila from Alto da Boa Vista and Agua Santa, RJ, and $1.07 \mathrm{ppm}$ (summer) against $B$. tenagophila from Pendotiba, RJ (Graphic I). LD90 values for animals from the last area were higher than those for animals from the remaining regions. Similarly two other tests carried out in the spring of 1988 and 1989, after periods of rain and at unseasonably cold temperatures, revealed LD90 values higher than 5.0 ppm. This latex of low activity was lyophilized in 1989 and after this process produced a lethality similar to that observed previously, i.e., $100 \%$ mortality starting from $0.8 \mathrm{ppm}$.

The tests with latex collected in Belo Horizonte and Recife revealed an LD90 of 0.73 and $1.33 \mathrm{ppm}$, respectively, i.e., values similar to those obtained for the reference material from Ilha do Governador, RJ (Graphic II).

\section{Evaluation of storage period}

\section{Latex in natura at room temperature}

After 3 days of storage at room temperature,

\section{GRAPHIC I}

Stability of the molluscicidal effect of the latex of Euphorbia splendens var. hislopii of the year.

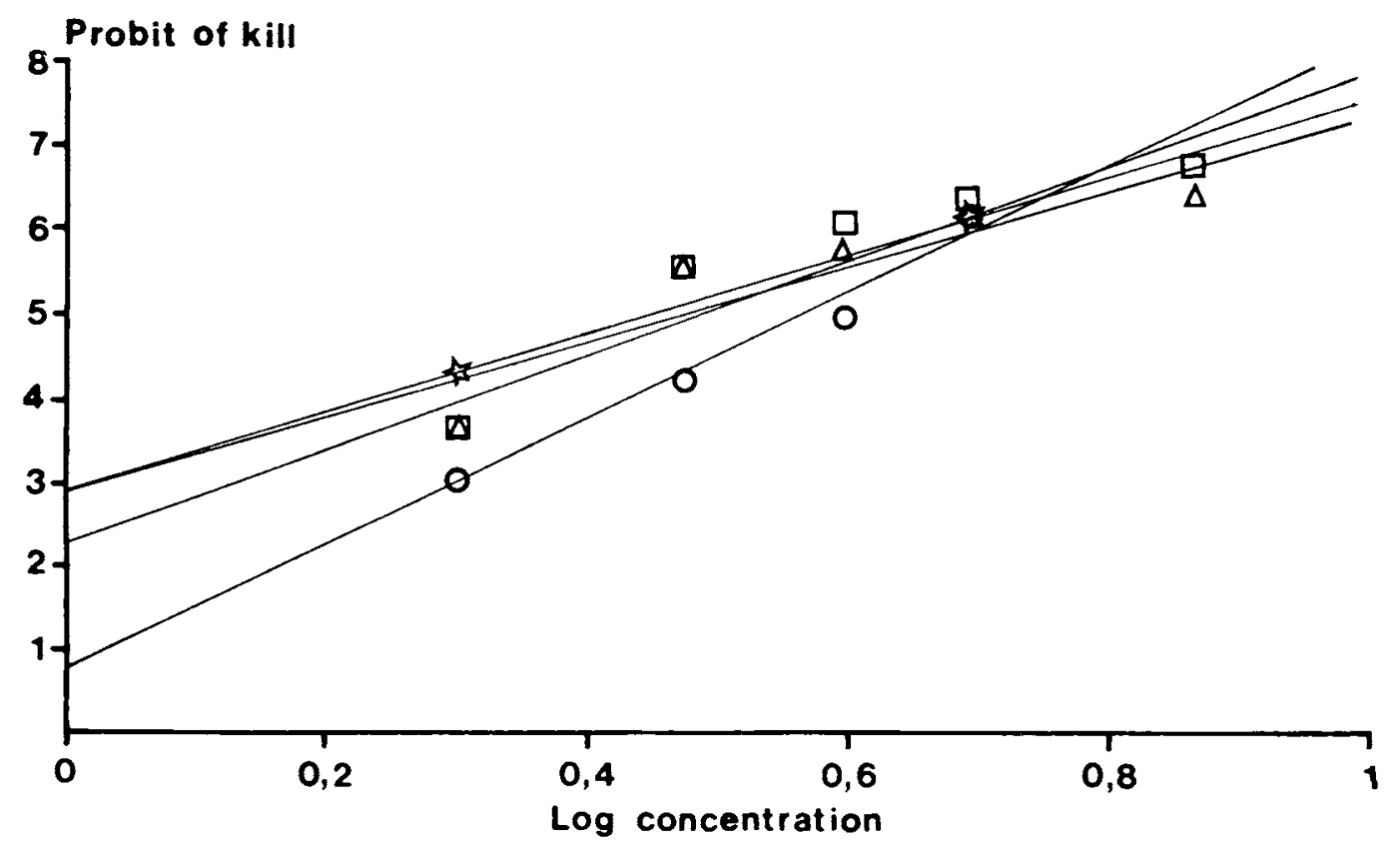

$๑$ Summer $\left(x^{2}=3,5\right) \square$ Fall $\left(x^{2}=14,0\right)-$ Winter $\left(x^{2}=9,2\right) \triangle$ Spring $\left(x^{2}=12,9\right)$ 
SCHALl, V. T.; VASCONCELlos, M. C. de; VILlAÇA-COELHO, A. L.; FERREIRA-LOPES, F. E. \& SILVA, I. P. da - Evaluation of temporal, seasonal and geographic stability of the molluscicidal property of Euphorbia splendens latex. Rev. Inst. Med. trop. S. Paulo, 34(3): 183-191, 1992.

\section{GRAPHIC ॥}

Geographic stability of the molluscicidal effect of the latex of Euphorbia splendens var. hislopii (Samples from Belo Horizonte (MG) and Recife (PE).

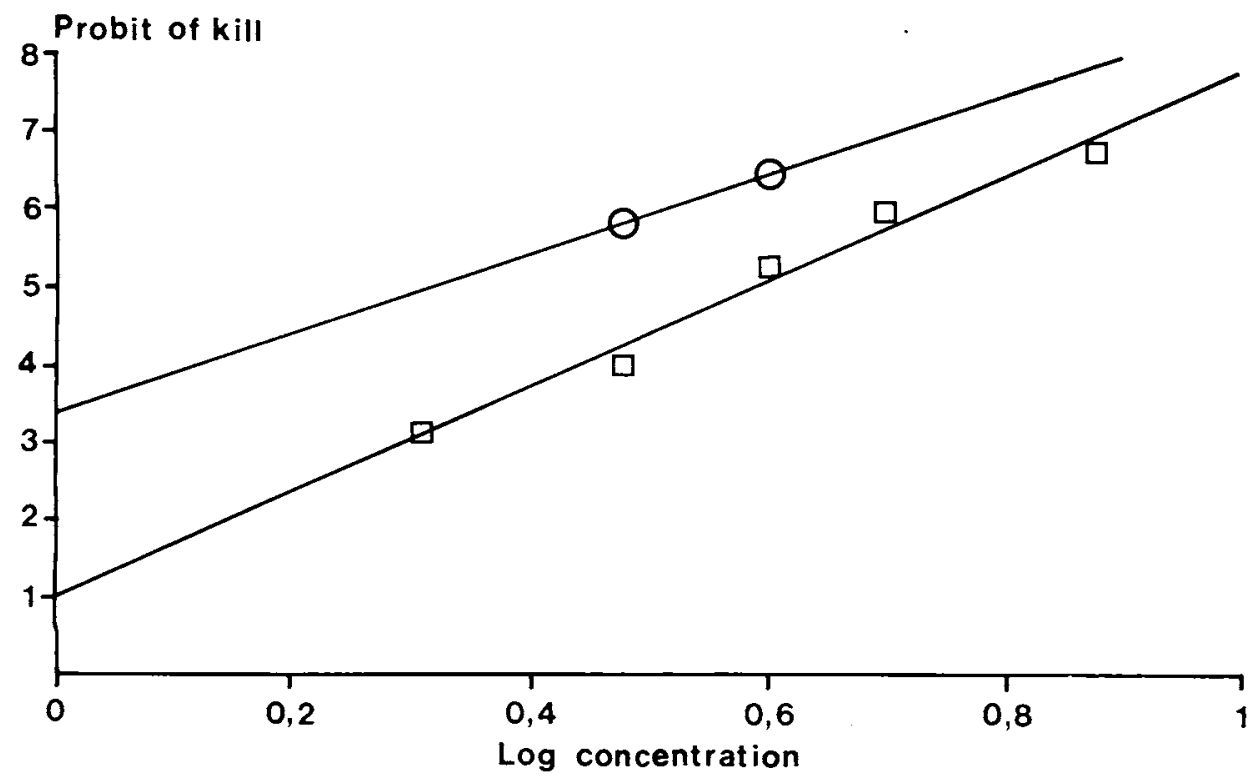

$$
\bigoplus \text { Belo Horizonte }\left(x^{2}=4,9\right) \quad \because \text { Recife }\left(x^{2}=13,6\right)
$$

the latex colected in November 1989, showed a LD90 of $1.14 \mathrm{ppm}$ on B. tenagophila from Agua Santa, RJ. After 43 days of storage a replicate resulted in an LD90 of $0.82 \mathrm{ppm}$. Finally after 124 days of storage (maximum time tested) a LD90 of $0.84 \mathrm{ppm}$ was observed against animals from the same collection area (Graphic III), demonstrating the molluscicidal action of the latex was stable over 4 months of storage.

\section{Centrifuged latex}

Bioassays of the precipitate and the supernatant from centrifuged la tex indicates that the former contained molluscicidal activity. This fraction was tested against B. glabrata from Touros, RN, maintained in the laboratory. Two subsequent tests after 35 and 61 days of storage using B. tenagophila from Agua Santa, revealed LD90 of 1.56 and $2.80 \mathrm{ppm}$, respectively, suggesting a gradual loss of molluscicidal activity with time.

\section{Lyophilized latex}

Bioassays of lyophilized latex, tested against B. glabrata from the laboratory, demonstrated $100 \%$ mortality starting from 1.0 ppm. Subsequent tests against B. tenagophila from Agua Santa and Jacarepagua using the lyophilized latex stored in the refrigerator at 10 to $12^{\circ} \mathrm{C}$, showed that the molluscicidal effect was maintained up to 736 days (more than 2 years) of storage (maximum time tested), the LD90 of $2.1 \mathrm{ppm}$, was a little higer than the range normally obtained for the newly collected material. However, the LD90 obtained after 370 days of storage was lower $(0.5 \mathrm{ppm})$ than the value obtained at 91 days $(1.5 \mathrm{ppm})$. Besides this, the LD90 of 129 days was $1.1 \mathrm{ppm}$, of 163 days was $1.4 \mathrm{ppm}$ and 197 days was $1.8 \mathrm{ppm}$, demonstrating that the molluscicidal activity seems to be slowly and gradatively diminishing, but still very efficient. 
SCHALL, V. T.; VASCONCELlos, M. C. de; VILLAÇA-COELHO, A. L.; FERREIRA-LOPES, F. E. \& SILVA, I. P. da - Evaluation of temporal, seasonal and geographic stability of the molluscicidal property of Euphorbia splendens latex. Rev. Inst. Med. trop. S. Paulo, 34(3): 183-191, 1992.

GRAPHIC III

Stability of the latex "in natura" of Euphorbia splendens var. hislopii storage at room temperature.

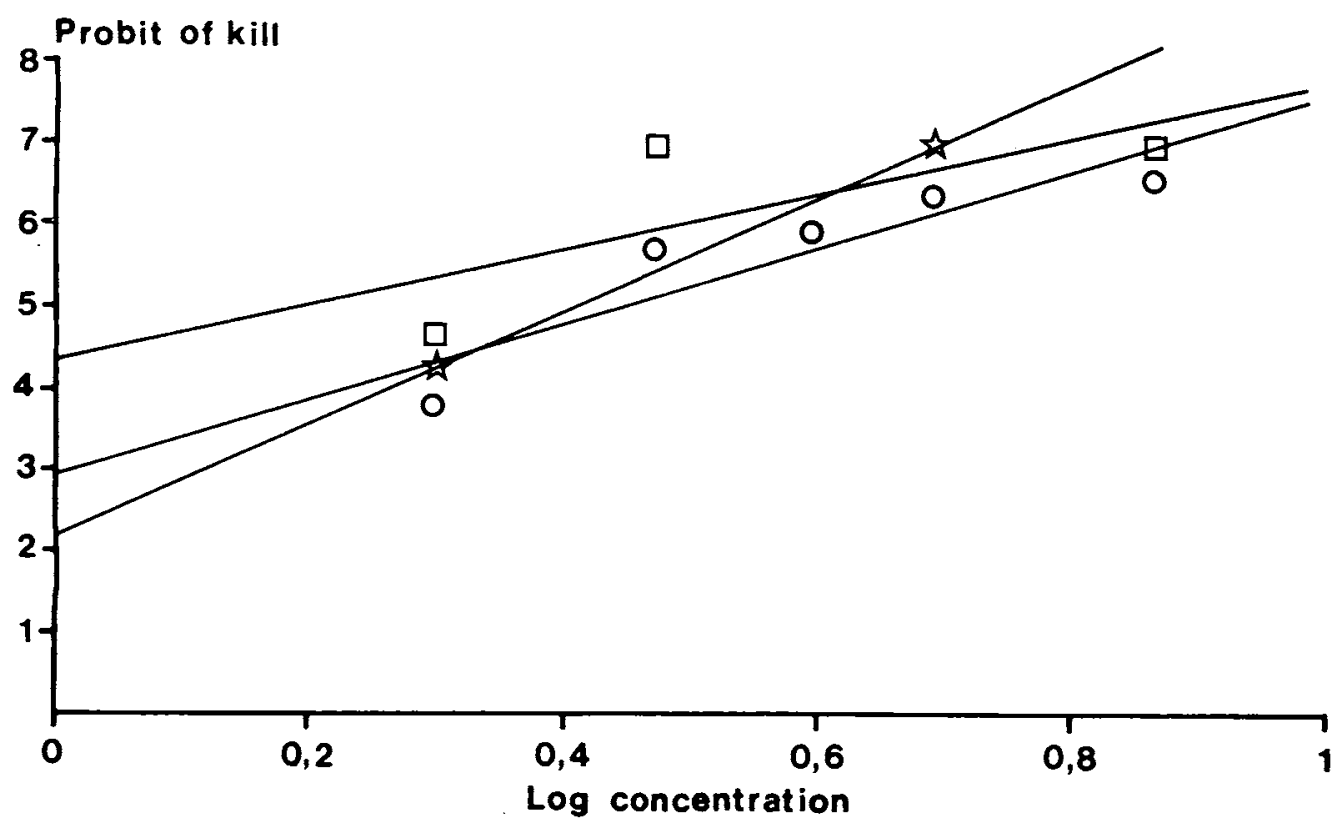

$$
3 \text { days }\left(x^{2}=1,2,9\right) \quad \square \quad \text { days }\left(x^{2}=19,7\right)
$$

Evaluation of the durability of the molluscicidal effect in the aquaria

The results showed that the $5.0 \mathrm{ppm}$ latex solution produced $100 \%$ mortality up to the 13 th day of the experiment (Table 1). 19 days old, solution was still lethal for $93.3 \%$ of the animals (only one surviing) (experiment $E$ ). During this phase the snails died gradually during the 4 days after their introduction into the aquarium and not on the first day after introduction as in experiments A, B and C of (Table 1). 22 days old, solution killed only 5 of the 15 animals submitted to the test, 10 being still alive after the 4 th day of the experiment (26th day, experiment $\mathrm{F}$ ( $\mathrm{Ta}$ ble 1). In all experiments, most of the control animals survived (Table 1 ). In the experiment $G$, (Table 1), deposited material was resuspended and the molluscicid activity was tested. Only 4 animals died after 5 days of observation. All this indicated a gradual loss of molluscicidal effect which suggested that the product is instable.
TABLE

Durability of the molluscicidal effect in the aquaria.

\begin{tabular}{|c|c|c|c|}
\hline \multirow{2}{*}{ Experiments } & \multirow{2}{*}{$\begin{array}{c}\text { Day of } \\
\text { Observation }\end{array}$} & $\begin{array}{l}\text { Number } \\
\text { Control } \\
\text { Situation }\end{array}$ & $\begin{array}{l}\text { of animais } \\
\text { Experimental } \\
\text { Situation }\end{array}$ \\
\hline & & Deads & Deads \\
\hline A & 2 & $0(0,0 \%)$ & $15(100 \%)$ \\
\hline B & 5 & $1(6,6 \%)$ & $15(100 \%)$ \\
\hline $\mathrm{C}$ & $\begin{array}{l}8 \\
9\end{array}$ & $\begin{array}{l}0(0,0 \%) \\
0(0,0 \%)\end{array}$ & $\begin{array}{l}14(93,3 \%) \\
15(100 \%)\end{array}$ \\
\hline $\mathrm{D}$ & $\begin{array}{l}12 \\
13\end{array}$ & $\begin{array}{l}4(26,6 \%) \\
4(26,6 \%)\end{array}$ & $\begin{array}{l}13(86,6 \%) \\
15(100 \%)\end{array}$ \\
\hline $\mathbf{E}$ & $\begin{array}{l}17 \\
18 \\
19\end{array}$ & $\begin{array}{l}0(0,0 \%) \\
0(0,0 \%) \\
0(0,0 \%)\end{array}$ & $\begin{array}{l}0(0,0 \%) \\
10(66,6 \%) \\
14(93,3 \%)\end{array}$ \\
\hline $\mathbf{F}$ & $\begin{array}{l}23 \\
24 \\
25 \\
26\end{array}$ & $\begin{array}{l}1(6,6 \%) \\
1(6,6 \%) \\
1(6,6 \%) \\
1(6,6 \%)\end{array}$ & $\begin{array}{c}0(0,0 \%) \\
2(13,3 \%) \\
5(33,3 \%) \\
10(66,6 \%)\end{array}$ \\
\hline $\mathbf{G}$ & $\begin{array}{l}27 \\
30 \\
31\end{array}$ & $\begin{array}{l}0(0,0 \%) \\
0(0,0 \%) \\
0(0,0 \%)\end{array}$ & $\begin{array}{l}1(6,6 \%) \\
3(20,0 \%) \\
4(26,6 \%)\end{array}$ \\
\hline
\end{tabular}


SCHALl, V. T.; VASCONCELlos, M. C. de; VILlaÇA-COELHO, A. L.; FERREIRA-LOPES, F. E. \& SILVA, I. P. $\mathrm{da}-$ Evaluation of temporal, seasonal and geographic stability of the molluscicidal property of Euphorbia splendens latex. Rev. Inst. Med. trop. S. Paulo, 34(3): 183-191, 1992.

\section{DISCUSSION}

The present study demonstrated the stability of the molluscicidal principle of $\mathbf{E}$. splendens latex over the 4 seasons of the year and after at least 4 months of storage. Thus, the latex satisfies important prerequisists set by the WHO (1965) such as: a) being an aqueous extract which is active at concentrations of less than $20 \mathrm{ppm}$, easy to collected and prepare; b) showing no toxicity to mice and rabbits (MATTOS et al, 1989, FREITAS et al., 1989, RIZZO \& PORFIRIO, 1971) or to man (RIZZO \& POR FIRIO, 1971) at the lethal dose found to snails; c) showing no acute toxicity or mutagenic activity at the concentrations that are been proposed for molluscicide (SCHALL et al., 1991); d) originating from an ornamental plant which does not inspire any aversion among the population leading to possible prejudice against its use; e) reported to have medicinal properties in other countries (LEE et al., 1982); f) adapted to the great majority of Brazilian regions, resistant, easy to cultivate and widely distributed all over Brazil.

These characteristics, taken as whole, represent a set of attributes that have not been detected in any other plant to be potentially used as a molluscicide in Brazil.

Among the most promising plants found to have a molluscicidal action, Phytolacca dodecandra, or ENDOD, which has been reported to be appropriate for the control of snail vectors of schistosomiasis by KLOOS \& McCULLOUGH (1982), who compared its action to that of synthetic molluscicides, as Niclosamide. However, this African plant is not common in Brazil and requires several years of growth before the first fruits from which the molluscicidal substance is extracted will ripen. In addition, the extraction process is responsible for variability in the lethal concentrations.

In contrast, since in $\mathbf{E}$. splendens it is the latex the part of the plant from which the molluscicidal principle is extracted, its easy tapping and preparation allow its utilization in a simple and inexpensive manner by rural communities in programs initially supervised but later selfsupported for the control of transmission. An additional advantage is that the plant is available throughout the year.

Furthermore, the active principle is also being investigated and highly active fraction against snails ( $L D 90=0.008 \mathrm{ppm}$ ) has been identified and has been found to be lethal for fish at 7 fold concentration (LD90 $=0.052 \mathrm{ppm})(\mathrm{ZA}-$ NI et al., 1989). This result is better than of niclosamide which is widely used in Brazil. The LD90 for snails of niclosamide is similar to the LD90 for fish (JURBERG et al., 1985).

However, as discussed by TANAKA et al, (1986), extrapolation of laboratory results to the field should be questioned, especially in terms of transposition of lethal doses and period of exposure to the substance.

A number of studies need to be conducted on this latex to establish the viability of snail control in small rural communities, as recommended by LUGT (1987). The agricultural aspects of $\mathbf{E}$. splendens should also be evaluated in order to determine an extraction cost unit capable of offering a measure of the latex volume extracted per cultivated area.

Other toxicologics studies are needed to conclude about the possible toxics properties of the substance and some of them are beeing done.

On the other hand the mechanism of action of the latex on mollusks should be investigated. SINGH \& AGARWAL (1988) demonstrated that E. royleana and $\mathbf{E}$. antisyphilitica act inhibiting acetylcholinesterase and reducing the levels of endogenous 5-hydroxytryptamine, epinephrine and dopamine in the nervous system of $\mathbf{L}$. acuminata, thus affecting the neurotransmitting mechanisms of the mollusks in an abrupt manner.

Considering the estimated number of Brazilians currently infected with $\mathbf{S}$. mansoni ( 6 to 8 million), the confirmation of the molluscicidal potential of latex from other regions of the country among those of highest disease endemicity (Minas Gerais and Northeast) has been described is highly positive, and it may represent a reduction in the costs involved in the control of Schistosomiasis disease in programs of local use by each community allied to a health education effort. 
SCHALL, V. T.; VASCONCELlOS, M. C. de; VILLAÇA-COELHO, A. L.; FERREIRA-LOPES, F. E. \& SILVA, I. P. $\mathrm{da}$ - Evaluation of temporal, seasonal and geographic stability of the molluscicidal property of Euphorbia splendens latex. Rev. Inst. Med. trop. S. Paulo, 34(3): 183-191, 1992.

\section{RESUMO}

Avaliação da estabilidade temporal, estacional e geográfica da ação moluscicida do latex da Euphorbia splendens.

Testes de laboratório com soluções aquosas do látex da Euphorbia splendens var. hislopii demonstraram uma estabilidade estacional da atividade moluscicida do produto coletado na Ilha do Governador - RJ, encontrando-se as seguintes DL90: 1,14 ppm (primavera); 1,02 ppm (outono); 1,09 ppm (inverno) e 1,07 ppm (verão) sobre Biomphalaria tenagophila de campo. Ensaios com o látex da planta coletado em Belo Horizonte e Recife, identificaram DL90 semelhantes aos da substância de referência coletada no Rio, demonstrando uma estabilidade geográfica do efeito moluscicida. Usando diluiçōes aquosas do latex in natura, centrifugado (precipitado) e liofilizado, observou-se a estabilidade da açāo moluscicida até 124 dias a temperatura ambiente (in natura) e até 736 dias, estocado em geladeira comum, entre 10 a $12^{\circ} \mathrm{C}$ (liofilizado). A 5,0 ppm é $100 \%$ letal para caramujos, até 13 dias após preparada, perdendo o efeito gradativamente até estar quase inativa no $30^{\circ}$ dia. Esta observaçāo indicou ser o princípio ativo instável. Tais características, associadas a larga distribuição da planta, sua resistência e adaptaçāo ao clima tropical, seu fácil cultivo, extração do látex e preparação da solução moluscicida, tornam o produto promissor para o uso em larga escala no contrôle da esquistossomose.

\section{ACKNOWLEDGMENTS}

The authors would like to thank the technical support of José Augusto Albuquerque dos Santos from Department of Biology. We are also very grateful to Dr. Margaret Emerich, from the Department of Botany to the National Museum (RJ), for plant identification and Darcilio Fernandes Baptista who collected the latex and a sample of the plant in Recife (PE).

\section{REFERENCES}

1. ABOU-EL-HASAN, A. A.; SOEB, A. H.; RAFWAN, A. S.; EL EMAN, E. R. \& AMIN. S. M. - The molluscicidal properties of Euphorbia lactea. In: INTERNATIONAL CONGRESS OF TROPICAL MEDICINE AND MALARIA, 20, Manila, $1980 . \quad$ Proceedings., 586, p. 360.
2. FARNSWORTH, N. R.; LOUB, W. D.; SOEJARTO, D. D. \& CORDEL, G. A. - Computer Services for research on plants for fertility regulation. Kor. J. Pharmacognosy, 12: $98-110,1981$

3. FINNEY, D, J. - Probit Analisys. 3rd. ed. New Delhi, Cambridge University Press, 1971. p. 333.

4. FREITAS, J. C. B.; PRESGRAVE, O. A. F.; FINGOLA F. F.; MENEZES, M. A. C.; VASCONCELLOS, M. C. SCHALL, V. T. \& PAUNGARTTEN, F. J. R. - Toxico logical study of the molluscicidal latex of Euphorbia splendens: irritant action on skin and eye. Mem. Inst. Oswaldo Cruz, 86 (suppl. 2): 87-88, 1991.

5. JURBERG, P.; CABRAL-NETO, J. B. \& SCHALL, V. T. - Molluscicide activity of the "avelos" plant (Euphorbia tirucalli, $L$.) on Biomphalaria glabrata, the mollusc vec tor of Schistosomiasis. Mem. Inst. Oswaldo Cruz, 80: 423-427, 1985 .

6. JURBERG, P.; VASCONCELLOS, M. C. \& MENDES, N M. - Plantas empregadas como moluscicidas: uma visão crítica. Mem. Inst. Oswaldo Cruz, 84 (suppl. 1): 76-83, 1985.

7. KLOOS, H. \& MeCUlLoUgh, F. S. - Plant Molluscicides. Planta méd., 46: 195-209, 1982.

8. KLOOS, H. \& MCCULLOUGH, F. S. - Plants with recognized molluscicidal activity. In: MOTT, K. E., ed. Plant Molluscicides. New York. UNDP/World Bank/WHO, 1987. p. 45-108.

9. KUO, Y. H. - Plant Molluscicide studieds in the People in Republic of China. In: MOTT, K. E. ed. Plant Molluscicides. New York. UNDP/World Bank/WHO, 1987. p. 229-298.

10. LEE, K. H.; HAYASHI, N.; OKANO, M.; HALL, I. H.; WU, R. Y. \& MacPAHIL, A. T. - Lasiodiplodin, a potent antileukemic macrolide from Euphorbia splendens. Phytochemistry, 2: 1119-1121, 1982.

11. LUGT, C. B. - Feasibility of growth and productions of molluscicidal plants. In: MOTT, K. E. ed. Plant Molluscicides. New York. UNDP/World Bank/WHO, 1987. p. 231-244.

12. MARSTON, A. \& HECKER, E. - On the active principles of the Euphorbiaceae VI. Planta méd., 47: 141-147, 1983.

13. MARSTON, A. \& HECKER, E. - Active principle of the Euphorbiaceae VII. Planta méd., 4: 285-364, 1984.

14. MATTOS, R. C.; VASCONCELlOS, M. C.; LOPES, M C.; SOUZA, C.A. M.; ALVES, E.N.; FARIAS, M.; SCHALL V. T. \& PAUMGARTTEN, F. J. R. - Estudo toxicológico do látex moluscicida da coroa de cristo (Euphorbia splen. dens var. hislopii). I. Ensaios preliminares. In: REUNIĀO ANUAL DA FEDERAÇÄO DE SOCIEDADES DE BIO LOGIA EXPERIMENTAL, 4. Caxambu, MG, 1989, p. 320.

15. MOTT, K. E. - Plant Molluscicides. New York. UNDP/ World Bank/WHO, 1987.

16. PEREIRA, J. P.; SOUZA, C. P. \& MENDES, N. M. - Pro- 
SCHALL, V. T.; VASCONCELLOS, M. C. de; VILLAÇA-COELHO, A. L.; FERREIRA-LOPES, F. E. \& SILVA, I. P. da - Evaluation of temporal, seasonal and geographic stability of the molluscicidal property of Euphorbia splendens latex. Rev. Inst. Med. trop. S. Paulo, 34(3): 183-191, 1992.

priedades moluscicidas da Euphorbia cotinifolia L. Rev. bras. Pesq. méd. biol., 11: 345-351, 1978.

17. PIO CORREA, M. - Dicionário de plantas úteis do Brasil e das exóticas cultivadas. Rio de Janeiro, Imprensa Nacional, Ministério da Agricultura, Instituto Brasileiro de Desenvolvimento Florestal, 1931. Vol. 2, p. 408.

18. RAO, C. B. \& SUSSELA, $\mathbf{K}$ - Chemical Examination of Euphorbia splendens Boj. Indian J. Chem., 21B: 495-496. 1982.

19. RIZZO, J. A. \& PORfírio, T. A. - Látex das Euphorbiaceas. Rev. goiana Med., 17: 155-162, 1971.

20. SCHALl, V. T.; VASCONCELLOS, M. C.; VALENT, G. U.; SATO, M. I. Z.; FURLAN, E. V. \& SANCHEZ, P. S. - Evaluation of the genotoxic activity and acute toxicity of Euphorbia splendens latex, a molluscicide for the control of schistosomiasis. Braz. J. med. biol. Res., 24: 573-582, 1991.

21. SILVA, M. J. M.; SOUZA, M. P. \& ROUQUAYROL, M. Z. - Atividade Moluscicida de plantas do Nordeste brasileiro (II). Rev. bras. Farm., 52: 117-123, 1971.

22. SINGH, A. \& AGARWAL, R. A. - Possibility of using latex of Euphorbiales for snail control. Sci. Total Environ., 77: $231-236,1988$.

23. TANAKA, H.; YASURAOKA, K. \& MCCULLOUGH, F. S. - Parameters used for assessment of molluscicides. Jap. J. exp. Med., 56: 189-194, 1986.

24. VASCONCELLOS, M. C. \& SCHALL, V. T. - Latex of coroa de cristo (Euphorbia splendens): An effective molluscicide. Mem. Inst. Oswaldo Cruz, 81: 475-476, 1986.

25. WORLD HEALTH ORGANIZATION - Molluscicide screening and evaluation. Bull. Wld. Hlth. Org., 33: 567-581, 1965.

26. WORLD HEALTH ORGANIZATION - Report of scientifie working group on plant molluscicide and guidelines for evaluation of plant molluscicide. Geneve, 1983, (TDR/SCH - SWE (4)/83.3).

27. ZANI, C. L.; PASSOS, L. K. J.; SOUZA, C.P.\& OLIVEIRA, A. B. - Bioassay guided phy tochemical study of the latex from Euphorbia splendens (Euphorbiaceae). Mem. Inst. Oswaldo Cruz, 84 (suppl. 1): 254, 1989.

Recebido para publicaçāo em 18/7/1991. Aceito para publicaçăo em $28 / 12 / 1991$. 